\title{
STATE IMPACT ON POTATO MARKET IN IRKUTSK REGION
}

\author{
Novikov A. \\ Faculty of Economics,Irkutsk State Academy of Agriculture \\ novirk@ya.ru
}

\begin{abstract}
Under the conditions of accession to the World Trade Organization (WTO) there is a particularly urgent problem of the provision of basic food products. One of the most important foods is potato. Potato is one of the few products for which the period of the reforms, there had been no sharp decline in production due to shortfalls in potato and other agricultural organizations almost full compensation due to its households producing potatoes for their own needs and remaining completely abandoned by the state. The main problem of the production and sales of potatoes is still a lack of state involvement in the formation and development of the potato market.
\end{abstract}

KEY WORDS:state impact, potato market, potato production, Irkutsk region

\section{INTRODUCTION}

Irkutsk Region is located at the southern part of the Eastern Siberia and part of the Siberian Federal District of the Russian Federation. The total area of the region is 767.9 thousand square $\mathrm{km}$, which is $4.6 \%$ of the territory of Russia. Based on the climatic conditions the territory of the Irkutsk region stands out among the other regions of the country, locating at the same latitudes, but it is in the European part of Russia or the Far East, so Irkutsk region has favorable natural conditions for the production of potatoes.

\section{METHODS AND MATERIALS}

The methodological basis of the study included the systemic and institutional approaches, as well as a variety of scientific methods, such as abstract logic, analysis and synthesis, Economics and Mathematics. The theoretical basis of the study is scientific works of Russian and foreign scientists
Among the subjects of the Russian Federation, in 2011, Irkutsk region takes the 19th place on the gross harvest of potatoes and the 5 th in the Siberian Federal District. Also it is significant that potato consumption is $127 \mathrm{~kg}$ per capita per year (30\% more than rational norm), indicating that the economic value of potatoes as a cheap and daily carbohydrate-containing food for the population of Irkutsk region.

involved in the development of the potato market, materials science conferences and monographs. The information base for the study is the official statistical data of the Federal Service of State Statistics of the Russian Federation. 


\section{RESULTS AND DISCUSSION}

Potato production in all categories of Irkutsk region in the years 1991-2012 decreased by 181.1 thousand tons or $22.7 \%$; potato acreage has decreased by 15.2 thousand hectares or $26.9 \%$, but the yield increased by 8.3 centers/ha or $5.8 \%$ (Table 1).

Table 1

Potato production by farm in Irkutsk region in 1991-2012

\begin{tabular}{|c|c|c|c|c|c|c|c|c|c|}
\hline \multirow[b]{2}{*}{ Data } & \multicolumn{8}{|c|}{ Years } & \multirow{2}{*}{$\begin{array}{c}2012 / \\
1991- \\
1995 \\
\text { years }\end{array}$} \\
\hline & $\begin{array}{l}1991- \\
1995\end{array}$ & $\begin{array}{l}1996- \\
2000\end{array}$ & $\begin{array}{l}2001- \\
2005\end{array}$ & 2008 & 2009 & 2010 & 2011 & 2012 & \\
\hline \multicolumn{10}{|c|}{ Alltypesoffarms } \\
\hline Sownarea, ha & 67.2 & 60.3 & 49.0 & 42.4 & 42.4 & 42.0 & 41.9 & 41.2 & 61.3 \\
\hline Yield, center/ha & 157.9 & 140.9 & 138.3 & 147.2 & 141.2 & 150.7 & 153.9 & 150.0 & 95.0 \\
\hline $\begin{array}{l}\text { Production, } \\
\text { thousandtones }\end{array}$ & 1061.0 & 849.7 & 677.9 & 624.0 & 598.7 & 632.9 & 644.7 & 617.8 & 58.2 \\
\hline \multicolumn{10}{|c|}{ Agriculturalorganizations } \\
\hline Sownarea, ha & 10.6 & 3.0 & 2.4 & 2.9 & 3.1 & 3.2 & 3.3 & 3.4 & 32.1 \\
\hline Yield, center/ha & 86.4 & 109.3 & 119.6 & 192.4 & 151.0 & 166.9 & 168.3 & 181.4 & 209.8 \\
\hline $\begin{array}{l}\text { Production, } \\
\text { thousandtones }\end{array}$ & 91.6 & 32.8 & 28.7 & 55.8 & 46.8 & 53.4 & 55.6 & 61.7 & 67.3 \\
\hline $\begin{array}{l}\text { Share in total } \\
\text { production, } \%\end{array}$ & 8.6 & 3.9 & 4.2 & 8.9 & 7.8 & 8.4 & 8.6 & 10.0 & 115.6 \\
\hline \multicolumn{10}{|c|}{ Peasant farms } \\
\hline Sownarea, ha & 0.4 & 0.8 & 0.9 & 1.3 & 1.6 & 1.4 & 1.3 & 1.3 & 325.0 \\
\hline Yield, center/ha & 97.5 & 107.5 & 111.1 & 203.8 & 116.9 & 145.7 & 143.2 & 149.7 & 153.5 \\
\hline $\begin{array}{l}\text { Production, } \\
\text { thousandtones }\end{array}$ & 3.9 & 8.6 & 10.0 & 26.5 & 18.7 & 20.4 & 18.6 & 19.5 & 499.0 \\
\hline $\begin{array}{l}\text { Share in total } \\
\text { production, } \%\end{array}$ & 0.4 & 1.0 & 1.5 & 4.2 & 3.1 & 3.2 & 2.9 & 3.1 & 856.9 \\
\hline \multicolumn{10}{|c|}{ Farmingpopulation } \\
\hline Sownarea, ha & 56.2 & 56.5 & 45.7 & 37.9 & 37.3 & 37.5 & 37.3 & 36.5 & 65.0 \\
\hline Yield, center/ha & 170.3 & 143.1 & 139.9 & 142.9 & 142.9 & 149.1 & 153.0 & 147.0 & 86.4 \\
\hline $\begin{array}{l}\text { Production, } \\
\text { thousandtones }\end{array}$ & 956.6 & 808.3 & 639.2 & 541.7 & 533.2 & 559.1 & 570.6 & 536.7 & 56.1 \\
\hline $\begin{array}{l}\text { Share in total } \\
\text { production, } \%\end{array}$ & 90.2 & 95.1 & 94.3 & 86.8 & 89.1 & 88.3 & 88.5 & 86.9 & 96.4 \\
\hline
\end{tabular}

The agricultural enterprises of Irkutsk region have potato acreage area which decreased from 15.3 to 2.1 thousand hectares from 1991 to 2006, and from 2006 to 2012 increased to 3.4 million hectares, cultivated areas in the households studied for years decreased from 56.4 to 36.5 thousand hectares. Gross harvest of potatoes in 2012 in all categories of Irkutsk region was 617.8 thousand tons, including agricultural organizations - 61.7 thousand tons, peasant farms -19.5 thousand tons and households -536.7 thousand tons by category of households in 2012, the largest share in the total harvest of potato farms owned by the population - $86.9 \%$, agricultural companies hold $10.0 \%$, peasant farms $-3.1 \%$.

Government influence in the regions of Russia is mainly aimed at agricultural organizations and peasant farms, although the main producer of potatoes is farming population.

One of the major problems in the production of potatoes is the reproduction of seed, since currently the elite seed potatoes in the Irkutsk region is almost not produced. The solution to this problem is possible only through the efforts of government agencies, as private households that produce most of the potatoes are not able to solve the problem on their own.

In our opinion, the state support households should also be provided for a system of partial refund of the purchase of high-quality potato seeds, machinery and equipment, fertilizers and crop protection from the budget.

In this regard, Figure 1 shows our proposed algorithm for seed potato production in Irkutsk region, which consists of three stages. 


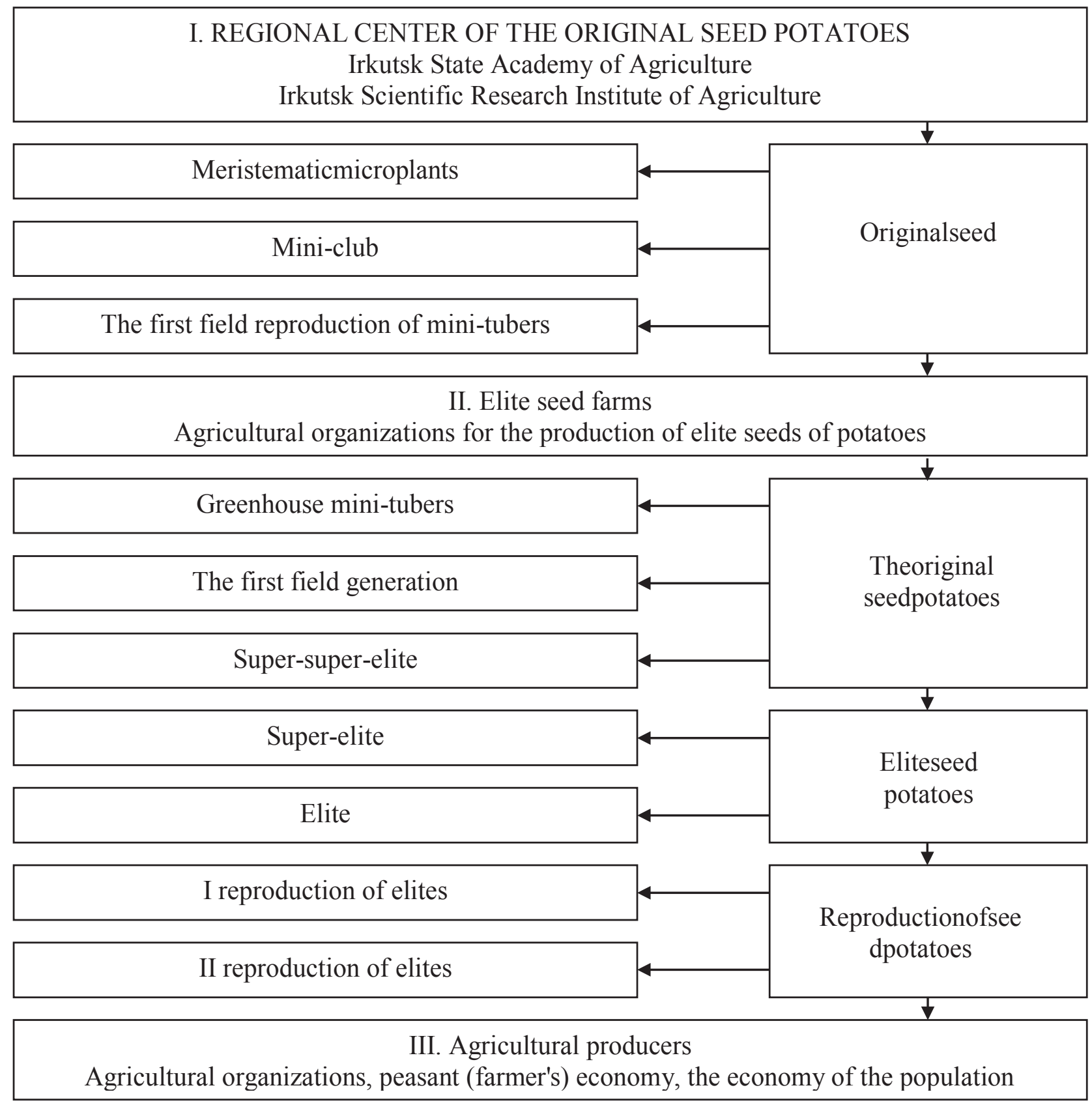

Figure 1. The algorithm of seed potatoes in Irkutsk region

The first step is the preparation of the starting seed sampled in the field or derived from tissue (meristem) culture. Mini-tubers are obtained and grown in pot plants (greenhouses, hydroponic modules, etc.).

The second stage involves the cultivation of original and elite seed potatoes, which cultivate in the respective nurseries. On the first and second stage potatoes are grown in the scientific institutions of agronomy and the high scientific level.

The third stage involves the cultivation of seed reproduction. Seed potatoes are grown elitist seed farms and provide the seeds of the first and subsequent reproductions of various agricultural organizations, peasant farms and personal farms. An analysis of recent data shows that the bulk of the seed of higher reproductions (mostly imported) is used primarily to land in agricultural organizations and some private peasant farms. Farming population is very rarely update their seeds and use the seeds of its own potatoes, which are massive and unknown reproductions, not even providing an average yield of potatoes in the Irkutsk region (about $150 \mathrm{~kg} / \mathrm{ha}$ ).

For routine strain renovation and sort changing in agricultural organizations and peasant farm it is recommended for every 100 hectares of planting 
acquire not less than 30 tones of the elite. Farming population should acquire elite seed once every three years and not less than $20 \%$ of the cultivated area.
On the basis of good practice routine and strain renovation sort changing algorithm of seed potato production we have determined the need of seed potatoes in Irkutsk region in 2014 by the original, and the elite of reproduction areas (Table 2).

Table 2

The structure of the needs in the various categories and classes of seed potatoes in Irkutsk region in

\begin{tabular}{|c|c|c|}
\hline $\begin{array}{l}\text { Categories and classes (generation) of } \\
\text { seed potatoes }\end{array}$ & $\begin{array}{l}\text { The need for seed } \\
\text { potatoes, tons }\end{array}$ & $\begin{array}{l}\text { Thestructure } \\
\text { needs, } \%\end{array}$ \\
\hline $\begin{array}{l}\text { Improved seed source material (mini-tubers, } \\
\text { the first field reproduction of mini-tubers) }\end{array}$ & 204 thousandsoftubers & $\mathrm{x}$ \\
\hline Super-super-elite & 213 & 0,3 \\
\hline Super-elite & 850 & 1,2 \\
\hline Elite & 3400 & 4,7 \\
\hline Reproduction I & 13600 & 18,8 \\
\hline Reproduction II & 54400 & 75,1 \\
\hline Total seed & 72463 & 100,0 \\
\hline
\end{tabular}

Thus, to ensure the potato crops in all categories of seed material and higher reproductions of systematic strain renovation and sort changing it is necessary to increase the production of elite potato to 3,400 tons, which will provide seed and commodity areas of reproduction (certified) material on the total sown area of potatoes in Irkutsk region.

\section{CONCLUSIONS}

1. The algorithm of seed potato production in Irkutsk region, which consists of three stages. The first step is the preparation of the starting seed, the second stage - the cultivation of original and elite seed potatoes, the third phase - growing brood of seed potatoes.

2. Systematic and strain renovation and sort changing of potatoes is proposed, which will establish the work on potato breeding and introduction of promising new varieties of seed potatoes to restore the system, increase the production of elite seeds of up to $3400 \mathrm{~m}$ (good

\section{REFERENCES}

1. Richkov V.A., Burlov S.P. Selection and seed potatoes in the Priangarie / Recommendation. - 2nd ed., Rev. and add. - Irkutsk: ISAA, 2011. - 49 pp. [in Russian].

2. Silaeva L.P. Development of potato market in the Russian Federation. - Moscow: AMBagro, 2001. - 192 pp. [in Russian].

3. Tulcheev V.V., Lukin, D.N. Organizational and economic basis for the development of

practice routine and strain renovation and sort changing, to develop and introduce new technologies of cultivation recognized varieties potatoes for seed and commercial products.

3. Thus, the system of state regulation of the potato should be a single set of measures, consisting of different types of action, aimed at the development of this market. The proposed activities of state influence in Irkutsk region will contribute to the organization of competitive market potatoes, and will improve the functioning of the business entities.

potato market and its products in Russia and in the world. - Moscow: Russian Agricultural Academy, 2008. - 272 pp. [in Russian].

4. Turco S.A., Rubel, M.I., Ivanyuk V.G. Handbook of Potato / RUE «Scientific and practical. Center of NAS of Belarus for Potato, Vegetable and Fruit». - Minsk, 2007. -165 pp. [in Russian]. 